\title{
A Note on Time Discretion and the Welfare Cost of Lump-Sum Taxation
}

\author{
Cristian F. Sepulveda \\ Department of Economics, Farmingdale State College, State University of New York, Farmingdale, NY, USA \\ Email: cristian.sepulveda@fa rmingdale.edu
}

How to cite this paper: Sepulveda, C.F. (2018) A Note on Time Discretion and the Welfare Cost of Lump-Sum Taxation. Theoretical Economics Letters, 8, 177-181. https://doi.org/10.4236/tel.2018.82013

Received: December 16, 2017

Accepted: February 5, 2018

Published: February 8, 2018

Copyright $\odot 2018$ by author and Scientific Research Publishing Inc. This work is licensed under the Creative Commons Attribution International License (CC BY-NC 4.0).

http://creativecommons.org/licenses/by/4.0/

\begin{abstract}
The lump-sum tax is broadly regarded by standard optimal tax theory as the only non-distortionary tax instrument; any other tax instrument distorts relative prices and thus creates a deadweight loss. This paper discusses an unintended effect of lump-sum taxation that can be considered a distortion of the time endowment. Whenever this tax exceeds the amount of non-labor income, it reduces the taxpayer's ability to freely allocate her time endowment. As long as the taxpayer assigns a positive value to time discretion, the lump-sum tax creates a welfare cost that has not been identified in the relevant literature. The welfare cost of the lump-sum tax could plausibly be greater than the traditional measure of deadweight loss of an equal yield labor income tax, which does not affect time discretion. Since the lump-sum tax does not unambiguously lead to a greater welfare level, we can conclude that it is not a proper efficiency standard at low levels of non-labor income. The same argument can be used to call for caution in the use of taxes based on the value of assets that are not the source of income flows, like owner-occupied property taxes and some types of wealth taxes. At low levels of non-labor income, these tax instruments will also have a negative effect on time discretion.
\end{abstract}

\section{Keywords}

Tax Distortions, Lump-Sum Tax, Labor Income Tax, Time Discretion

\section{Introduction}

Lump-sum taxation is widely regarded in standard optimal tax theory as the only efficient or non-distortionary tax instrument. In order to collect a given amount of revenue, any other tax reduces taxpayer's welfare more than the lump-sum tax, imposing a deadweight loss to society. ${ }^{1}$ This paper argues that ${ }^{1}$ For an overview of the standard optimal tax theory, see Auerbach and Hines [1]. 
when the lump-sum tax exceeds the amount of non-labor income, it becomes a tax on the time endowment, or a time tax, because the taxpayer is forced to work a certain period of time without pay. This effect of lump-sum taxation can be interpreted as a loss of taxpayer discretion over her time endowment, and can even be considered a form of forced or compulsory labor. ${ }^{2}$

This short paper compares the effects of the lump-sum tax on taxpayer's time discretion with the effects of the labor income tax, which does not impose restrictions on the time endowment. In the presence of time discretion losses, the welfare cost of the lump-sum tax may well exceed the distortions imposed by other tax instruments. In this context, the choice between lump-sum and labor income taxation is made by comparing two types of distortion, and the lump-sum tax cannot be regarded as a proper standard of efficiency.

Time discretion losses can also be caused by taxes on the value of assets that are not the source of income flows, such as owner-occupied property taxes and other forms of wealth taxes. At low levels of non-labor income, these tax instruments will also have a negative effect on time discretion, becoming time taxes. Moreover, provided that a lower level of non-labor income is associated with greater discretion losses, time taxes can be expected to be regressive. ${ }^{3}$ The net welfare cost of time discretion losses may help explain the unpopularity of the lump-sum tax and other taxes with similar effects on the time endowment. ${ }^{4}$

\section{On the Value of Time Discretion}

The lump-sum tax is considered non-distortionary by definition, because it does not depend on taxpayer's behavior. Any given amount of revenue collected through a distortionary tax can also be collected as a lump-sum tax without distorting relative prices. The lump-sum tax, however, has an unintended consequence that has not been described in the related literature. When it is greater than non-labor income, the taxpayer is forced to work to pay the tax, and thus her time discretion is reduced.

${ }^{2}$ The Forced Labour Convention of 1930 [2] defines forced or compulsory labor in its Article 2 as "all work or service which is exacted from any person under the menace of any penalty and for which the said person has not offered himself voluntarily". Assuming that tax compliance is enforced and that the taxpayer would not offer herself voluntarily to work in any job without pay, then the definition describes the case analyzed in this paper. The same Convention excludes from this definition "any work or service which forms part of the normal civic obligations of the citizens of a fully self-governing country" as well as other types of work and services; however, we may argue that labor provided exclusively to pay a tax cannot be considered as a "normal civic obligation". This Convention also states in its Article 10 that "[f]orced or compulsory labour exacted as a tax [...] shall be progressively abolished".

${ }^{3}$ The negative welfare effects of time taxes can be especially acute if individuals are already time-poor. Vickery [3] defines time-poverty as spending too much time in market work and too little in nonmarket work. A small but growing body of literature emphasizes the time dimension of wellbeing, and suggests that the income-poor have limited access to market goods that save household production time [4] and have access to a lower quality of leisure [6].

${ }^{4}$ Lump-sum and wealth taxes have for long been recognized as unpopular in the literature. For instance, the discontent produced by the implementation of a lump-sum tax in the United Kingdom is considered one of the factors leading to Margaret Thatcher's resignation as Prime Minister in 1990 [6]. The unpopularity of property taxes and other taxes on wealth has been widely documented. See Pagano and Jacob [7]. 
The reduction of time discretion is described in Figure 1, which also shows the way in which the current literature defines tax distortions and the concept of deadweight loss (see Auerbach and Hines [1]). Non-labor income is for simplicity assumed to be zero. Taxpayer's income $y$ increases upward in the vertical axis; leisure $\rho$ increases rightward in the horizontal axis, where $\kappa$ represents the time endowment. The initial budget constraint is the line connecting $a$ and $\kappa$. A loss of time discretion means that that the taxpayer is no longer able to freely allocate her time endowment between leisure and labor. Graphically, this loss is shown by a movement of the intercept of the budget constraint with the horizontal axis to the left of $\kappa$, such that $\rho=\kappa$ is not feasible anymore. Without non-labor income, a lump-sum tax $s$ reduces time discretion in $s / w$ units of time, where $w$ denotes the wage rate.

Standard optimal taxation theory pays no attention to the effect of lump-sum taxation on the time endowment, and consequently assumes (implicitly) that the loss of time discretion has no effect on taxpayer's welfare. In this framework lump-sum taxation imposes a welfare cost lower than any other tax instrument. Figure 1 compares the welfare effects of lump-sum and labor income taxes. The initial equilibrium is at $e_{0}$, where the budget constraint is tangent to the indifference curve $u_{0}$. A labor income tax rate $t$ reduces the wage rate from $w_{0}$ to $w_{1}=(1-t) w_{0}$, rotating the budget constraint over $\kappa$ without affecting time discretion. The new optimum under $t$ is at $u_{1}$, and tax revenue $R$ is equal to the vertical difference between the equilibrium point $e_{1}$ and the original budget constraint. The labor income tax is considered inefficient because an equal yield lump-sum tax $s=R$ allows the taxpayer to reach a higher level of utility $u_{2}$. Using the expenditure function $E\left(w_{0}, u_{i}\right)$ to represent the minimum expenditure required to reach the utility level $u_{i}$ with the wage rate $w_{0}$, the equivalent variation measure of the deadweight loss of the labor income tax is $D W L=E\left(w_{0}, u_{0}\right)-E\left(w_{0}, u_{1}\right)-R$.

The relative benefit of lump-sum taxation has been obtained in this case at the expense of a loss of time discretion equal to $\kappa-\pi$. Standard economic theory is silent about the welfare value of time discretion, but it implicitly assumes that

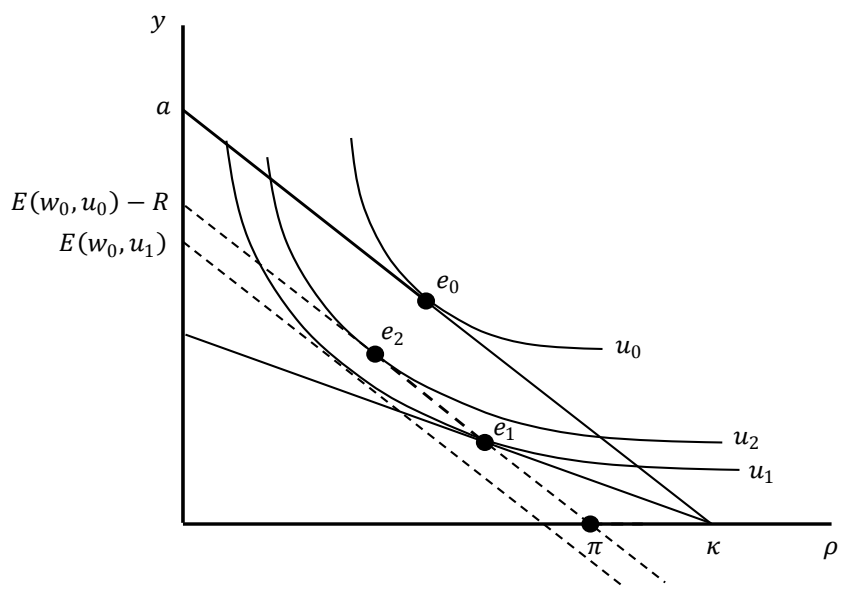

Figure 1. Welfare effects of lump-sum and labor income taxes. 
the value of each unit of time discretion lost is equal to the wage rate, the opportunity cost of leisure. This implies that the monetary value of $\kappa-\pi$ is equal to $(\kappa-\pi) w_{0}=s$, the intended tax burden. The problem with this approach, however, is that the reduction of income and the reduction of time discretion are different in nature. While lower income means that some baskets of goods and services are no longer affordable, reduced time discretion implies that, in addition, the taxpayer has lost part of her ability to freely allocate her time endowment. The value of $\kappa-\pi$ is simply not meant to be captured by the standard time allocation model. Indeed, according to the latter the taxpayer could (quite literally) be enslaved by means of the lump-sum tax without increasing the welfare costs above the amount of the tax itself.

The effective value of time discretion depends on the uncertainty faced by the taxpayer in the period between the implementation of tax policy and the completion of the time allocation decision. To illustrate this point, consider two alternative tax schedules. Schedule 1 is a 20 percent tax rate on the wage rate, under which the taxpayer will choose to work six hours per day from Monday to Friday. Under schedule 2, equivalent to an equal yield lump-sum tax, there is no proportional reduction in the wage rate, but the first six hours of labor supplied on Monday are unpaid. In Figure 1 the equilibrium under schedule 1 would correspond to $e_{1}$, and under schedule 2 to $e_{2}$. As long as preferences are convex, standard optimal taxation theory predicts that the taxpayer would invariably be better off under the second alternative. But in order for this conclusion to be correct, the lump-sum tax must be set before point $e_{1}$ has been reached, otherwise there would be no time left to be allocated and $e_{2}$ would no longer be feasible. The implementation of the lump-sum tax must take place before the time allocation decision is made, when the taxpayer is not certain about how much time she will be able and willing to work during the week. Different possible scenarios that could take place before or during the week (e.g. sickness, family emergencies, etc.) may also affect taxpayer's time discretion and, consequently, shift the budget constraints and change her optimal labor decisions and utility levels under $s$ and $t$. Let each of the $N$ possible levels of time discretion be associated with a probability $p_{n}$, where $n=1, \cdots, N$. Both the optimal labor decisions as well as the corresponding levels of utility under the lump-sum tax $\left(u_{n}^{s}\right)$ and under the labor income tax $\left(u_{n}^{t}\right)$ can be expected to vary at each level of time discretion. Note that the two tax instruments cannot be constrained to collect the same amount of revenue at each level of time discretion. In this context, it is not necessarily the case that the expected utility under the lump-sum tax, $\sum_{n=1}^{N} p_{n} u_{n}^{s}$, is greater than the expected utility under the labor income tax, $\sum_{n=1}^{N} p_{n} u_{n}^{t}$, or that the $D W L$ of the labor income tax (as computed by the standard theory) is greater than its expected utility gains with respect to the lump-sum tax. ${ }^{5}$

${ }^{5} \mathrm{~A}$ more complete account of the welfare effects of these taxes may include the taxpayer's attitude toward risk and the cost of eliminating uncertainty with the use of insurance, but they are not considered here because they would add nonessential complications to the main argument presented in this paper. 


\section{Conclusion}

When a lump-sum tax exceeds the amount of non-labor income, time discretion is reduced and the taxpayer is forced to work without pay. The associated welfare cost is not accounted for in standard optimal taxation theory, implying that the deadweight loss of taxes other than lump-sum can be overestimated. In particular, labor income taxation allows the taxpayer to enjoy full discretion over the available tax endowment. If the welfare gains from full time discretion are equal to or greater than the traditional measure of deadweight loss, we can conclude that the labor income tax is not distortionary. It follows that at low levels of non-labor income the lump-sum tax may not be a proper standard of efficiency for the design of tax policy; and that other taxes that affect time discretion, like those based on the value of assets that generate no explicit income, create welfare costs that are underestimated by the standard theory of optimal taxation.

\section{References}

[1] Auerbach, A. and Hines, J. (2002) Taxation and Economic Efficiency. In: Auerbach, A. and Feldstein, M., Eds., Handbook of Public Economics, Elsevier, Amsterdam, 1347-1421.

[2] International Labour Organization (1930) Forced Labour Convention, 1930 (No. 29), Convention Concerning Forced or Compulsory Labour. Geneva. http://www.ilo.org/dyn/normlex/en/f?p=NORMLEXPUB:12100:0::NO::P12100_IL O_CODE:C029

[3] Vickery, C. (1977) The Time-Poor: A New Look at Poverty. The Journal of Human Resources, 12, 27-48. https://doi.org/10.2307/145597

[4] Antonopoulos, R., Masterson, T. and Zacharias, A. (2012) The Interlocking of Time and Income Deficits: Revisiting Poverty Measurement, Informing Policy Responses. Undoing Knots, Innovating for Change 3, United Nations Development Programme.

http://www.undp.org/content/dam/undp/library/gender/Gender\%20and\%20Povert y\%20Reduction/Time\%20deficits\%20poverty.pdf

[5] Merz, J. and Rathjen, T. (2014) Time and Income Poverty: An Interdependent Multidimensional Poverty Approach with German Time Use Diary Data. Review of Income and Wealth, 60, 450-479. https://doi.org/10.1111/roiw.12117

[6] Mankiw, N.G., Weinzierl, M. and Yagan, D. (2009) Optimal Taxation in Theory and Practice. Journal of Economic Perspectives, 23, 147-174.

https://doi.org/10.1257/jep.23.4.147

[7] Pagano, M.A. and Jacob, B. (2010) Framing the Political Economy of Property Taxation and Land Taxation. In: Bahl, R., Martinez-Vazquez, J. and Youngman, J., Eds., Challenging the Conventional Wisdom on the Property Tax, Lincoln Institute of Land Policies, Cambridge, Massachusetts, 269-292. 